\title{
SPIB Gene
}

National Cancer Institute

\section{Source}

National Cancer Institute. SPIB Gene. NCI Thesaurus. Code C99651.

This gene is involved in the modulation of gene transcription. 